\title{
THE DIATOM STRATIGRAPHY AND PALEOECOLOGY OF LAKE OHRID, YUGOSLAVIA
}

\author{
ADRIENNE KEHDE ROELOFS ${ }^{1}$ and PETER KILHAM \\ School of Natural Resources, The University of Michigan, Ann Arbor, MI 48109 (U.S.A.) \\ Division of Biological Sciences, The University of Michigan, Ann Arbor, MI 48109 (U.S.A.)
}

(Received June 15, 1982; revised version accepted January 25, 1983)

\begin{abstract}
Roelofs, A.K. and Kilham, P., 1983. The diatom stratigraphy and paleoecology of Lake Ohrid, Yugoslavia. Palaeogeogr., Palaeoclimatol., Palaeoecol., 42: 225-245.
\end{abstract}

An $8.85 \mathrm{~m}$ core (No. 9) was taken from Lake Ohrid, Yugoslavia, in August 1973 at a depth of $210 \mathrm{~m}$, approximately $6 \mathrm{~km}$ offshore of Gorica, Yugoslavia. The core was sampled at $10-\mathrm{cm}$ intervals and analyzed for moisture, organic and $\mathrm{CaCO}_{3}$ content, and diatoms.

There is a slight but steady decrease of moisture with depth, probably due to sediment compaction. The organic content showed little variation throughout the core $(\bar{x}=2.73 \pm$ $0.39 \%$ of total weight). The $\mathrm{CaCO}_{3}$ content from $885-110 \mathrm{~cm}$ depth also showed little change $(\bar{x}=2.32 \pm 0.55 \%$ of total weight) but increased in the top meter of the core $(100-0 \mathrm{~cm}, \bar{x}=11.03 \pm 8.86 \%$ of total weight). Throughout the core there is an inverse relationship between organic and $\mathrm{CaCO}_{3}$ content, particularly in the top meter.

Extrapolation to the bottom of the core using linear regression based on ${ }^{14} \mathrm{C}$-dating yields a date of ca. 30,000 years B.P.

Results indicate that Lake Ohrid has remained an oligotrophic lake throughout the period represented by Core 9 . Diatom analysis shows one persistent group of diatoms throughout the core. This group consists of Cyclotella fottii, C. hustedtii, and C. hustedtii var. 1 and is referred to as the Cyclotella complex.

Between $885-650 \mathrm{~cm}$ (ca. 30,000-20,000 yr B.P.) there is a sharp increase in numbers and a slight increase in diversity of species. This may correspond with the beginning of the warmer, more humid middle Pleniglacial.

Between 650-100 cm (ca. 20,000-10,000 yr B.P.) the Cyclotella complex appears usually alone in small numbers. There are a few other scattered species in this section, mainly Opephora martyi and Fragilaria pinnata. This section of the core probably corresponds with the cold upper Pleniglacial of the Würm (Weichselian).

Between 100-0 cm (ca. 10,000-0 yr B.P.) there is the largest increase in number and diversity of species, particularly above $60 \mathrm{~cm}$. The Cyclotella complex, C. ocellata, Cyclotella sp.1, Stephanodiscus astraea var. intermedia fo.1 and Stephanodiscus sp.1 are dominant. This is the only section of the core in which Stephanodiscus species occur, and probably corresponds with the Holocene.

\footnotetext{
${ }^{1}$ Present address: Department of Botany, The University of British Columbia, Vancouver, B.C. V6T 1W5 (Canada).
} 


\section{INTRODUCTION}

Lake Ohrid is one of the large (surface area $=348 \mathrm{~km}^{2}$ ), deep (maximum depth $=298 \mathrm{~m}$, mean depth $=145 \mathrm{~m}$ ) and ancient lakes of the world. Some geologists believe that the southern basin of the lake is of Miocene age (Ivanovski and Strackkov, 1974) and it is generally agreed that the lake has existed in its present form since the Pliocene (Stanković, 1960; Ivanovski and Strack kov, 1974). The marked endemism of Lake Ohrid's fauna and flora attests to the great antiquity of the lake (Stanković, 1960). This initial paper on the paleolimnology of Lake Ohrid is focused on the diatom stratigraphy of an $8.85 \mathrm{~m}$ sediment core.

The four lakes of the Dassaretes (Lakes Ohrid, Prespa, Korča, and Bilište)

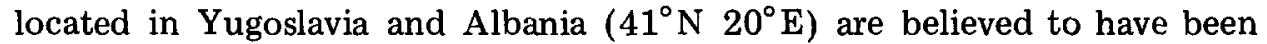
connected until the late Pliocene or early Pleistocene (Stanković, 1960; Ivanovski and Stračkov, 1974) when tectonic events occurred which closed the connections. Korta and Biliste eventually became dry lacustrine basins. Prespa is now a shallow (mean depth $=19-20 \mathrm{~m}$ ) oligotrophic, calcareous, graben lake-(Stanković and Šapkarev, 1959; Kozarov, 1960).

Lake Ohrid is also an oligotrophic, calcareous, graben lake. The chemical and physical limnology, general history, and endemism of the lake have been extensively investigated (Stanković and Hadžiše, 1953; Stanković, 1960). Zooplankton (Serafimova-Hadžišce, 1959), bacteria (Ocevski, 1953, 1958a, b), phytoplankton population dynamics (Kozarov, 1954, 1958), and primary production by phytoplankton (Kozarov, 1959; Allen and Ocevski, 1976) have also been studied.

These investigations indicate that the present highly oligotrophic state of the lake is possibly maintained through the suppression of photosynthetic activity as a consequence of Lake Ohrid's physical and chemical characteristics. It is a marl-producing lake that is generally oligomictic. With the exception of occasional winter overturn, the lake is thermally stratified with an upper heterothermic layer $(0-70 \mathrm{~m})$ and a lower homothermic layer $(70-298 \mathrm{~m})$. The temperature of the lake is always above $4^{\circ} \mathrm{C}$. The highly stable thermal characteristics of Lake Ohrid can be attributed to a very stable summer stratification caused by intense insolation, shelter from the winds by the high mountains, and to an upper heterothermic zone isolated from a massive hypolimnion with almost no variation in temperature (Stanković, 1960).

Lake Ohrid has a very high transparency (1\% of the light penetrating the surface reaches depths of 30-35 m; Stankovic, 1960) owing to the low abundance of phytoplankton and low allochthonous detritus. The lake is fed almost exclusively by underground karstic springs. Detrital material apparently settles out of the influent water underground before it enters the lake.

Lake Ohrid is a typical calcium-bicarbonate marl lake, in which $\mathrm{Ca}\left(\mathrm{HCO}_{3}\right)_{2}$ predominates. There is frequent precipitation of $\mathrm{CaCO}_{3}$ in the littoral zone, particularly during periods of peak phytoplankton photosynthesis (Stanković, 1960). 
Wetzel (1975) describes marl lakes as a "type of maintained oligotrophy" where reduced productivity is maintained by decreased nutrient availability rather than "true" oligotrophy, in which nutrient inputs to the system are deficient. Decreased nutrient availability is due to adsorption of phosphate, iron, manganese, and organic compounds to colloidal and sedimenting particulate $\mathrm{CaCO}_{3}$. These particles are insoluble and thus are effectively lost to the system owing to sedimentation. Bioassay experiments (Allen and Ocevski, 1976) appear to indicate that the phytoplankton in Lake Ohrid are often limited by silica, phosphorus, iron, etc.

The purpose of this study was to determine the extent to which the present oligotrophy and unique endemism represented by the diatom community was typical of the past. The core which was examined allows interpretation of the diatom stratigraphy in relation to the degree of oligotrophy, and chemical-physical, climatic, and cultural changes over the past 30,000 years of lacustrine history.

\section{METHODS}

\section{Collection of the core}

The $8.85 \mathrm{~m}$ core (No. 9) was taken in August 1973 by André Lambert and Peter Kilham at a depth of $210 \mathrm{~m}$ approximately $6 \mathrm{~km}$ offshore of Gorica, Yugoslavia (Fig.1). A modified Kullenberg corer was used. This corer was designed and constructed by Uli Briegel of the Eidg. Technische Hochschule in Zürich, Switzerland. Cores were collected in plastic liners (drain pipe) that had a $6 \mathrm{~cm}$ inside diameter. After collection the core was split longitudinally and sampled for diatom, chemical, and radiocarbon analyses.

\section{Radiocarbon dating}

Samples were taken between $76-80 \mathrm{~cm}$ (No. GX-5848), 160-170 cm (No. GX-6372), and $300-310 \mathrm{~cm}$ (No. GX-6373). The samples were radiocarbon dated after treatment to remove carbonates by Krueger Enterprises, Cambridge, MA., U.S.A. The dates are based on a Libby half life of $\mathbf{5 5 7 0}$ years for ${ }^{14} \mathrm{C}$.

\section{Chemical profiles}

Samples ( $\bar{x}=1.96 \pm 0.41$ gram wet weight) were taken at $10 \mathrm{~cm}$ intervals for analysis of moisture, organic, and $\mathrm{CaCO}_{3}$ content. Moisture content was determined by weight loss of fresh sediment after $24 \mathrm{~h}$ at $110^{\circ} \mathrm{C}$. A modified ignition loss method (Dean, 1974) was used to determine organic and carbonate content. Organic content was estimated by weight loss from dried sediment, after $4 \mathrm{~h}$ at $550^{\circ} \mathrm{C}$. Carbonate content was determined by weight loss of dried sediment after $4 \mathrm{~h}$ at $1000^{\circ} \mathrm{C}$. The $\mathrm{CO}_{2}$ content was converted to $\mathrm{CaCO}_{3}$ by multiplying by 2.27 . 


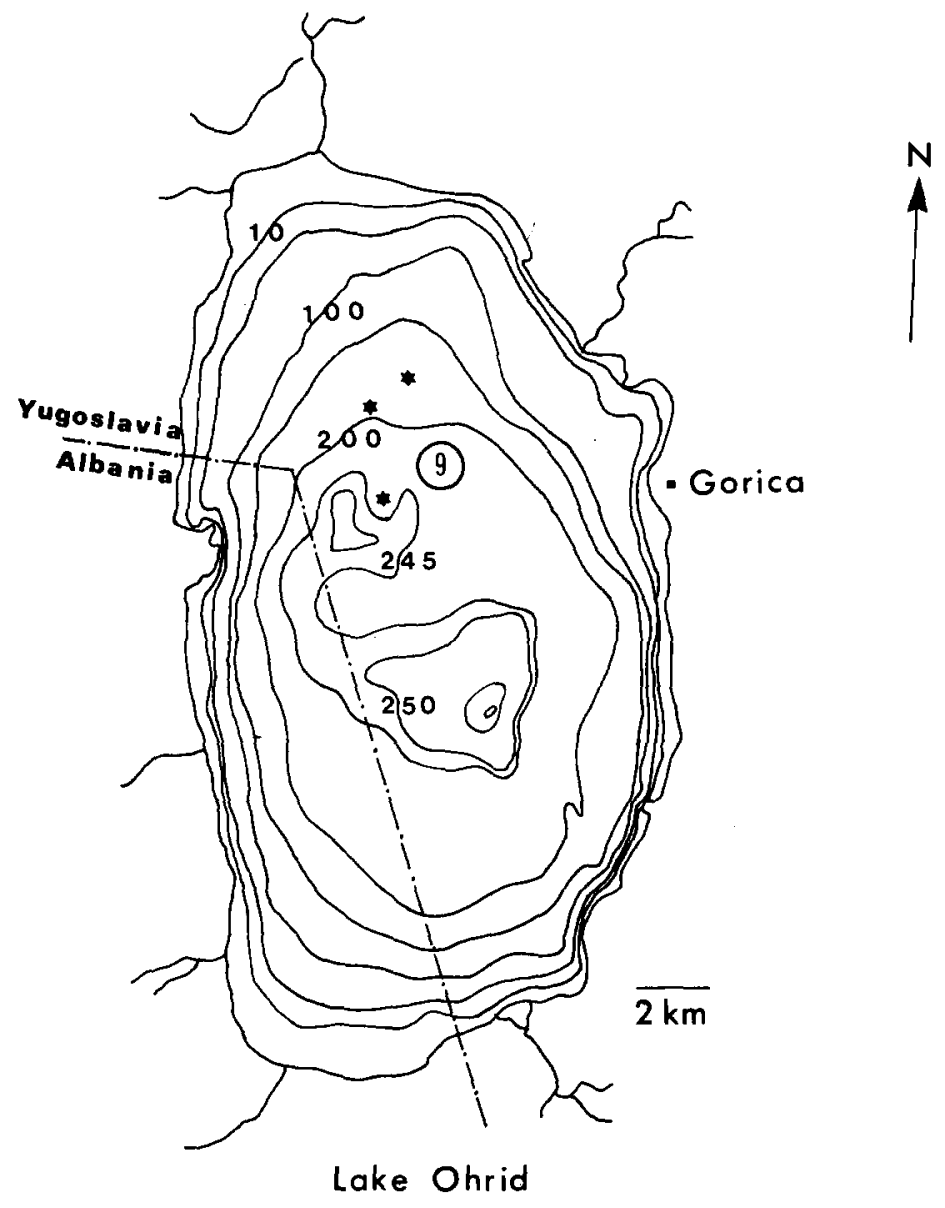

Fig.1. Location of sediment Core 9 and surface sediment samples (*), August 1973 (redrawn after Allen and Ocevski, 1976). Contours are in meters.

\section{Diatom profile}

Sediment samples were removed at the same $10 \mathrm{~cm}$ intervals by pressing a size 00 gelatine capsule into the non-smeared inner surface of the core (Stevenson, 1968). Carbonate was removed with a $10 \% \mathrm{HCl}$ solution, and dichromic acid solution was used to oxidize organic matter. Counts were made for each sample and expressed as numbers of valves/gram dry weight. Counting and identification of diatoms were done under oil immersion using a Zeiss Standard Research microscope with Nomarski optics. 
RESULTS

\section{Core lithology}

The core displayed a distinct change in lithology over the top meter. From 0-20 cm the sediment was olive gray to olive (Munsell Soil Color Chart, $1975 ; 5 Y 5 / 2-5 / 3)$ and from $21-96 \mathrm{~cm}$, black (5Y 2.5/1). The remainder of the core varied around dark gray (5Y 4/1).

\section{Radiocarbon dating}

The ${ }^{14} \mathrm{C}$-dating of the core is shown in Fig.2. Extrapolation to the bottom of the core using linear regression $(D=0.046 T-496.9 ; D=$ depth of sediment in $\mathrm{cm}$ and $T=$ time in years) yields a date of ca. 30,000 yr B.P. Below approximately $70 \mathrm{~cm}$ the ${ }^{14} \mathrm{C}$-dating gives a sedimentation rate of $0.045 \mathrm{~cm}$ $\mathrm{yr}^{-1}$. Lead-210 dating (Robbins, 1978) of a $20 \mathrm{~cm}$ core taken near the Core 9 site gave a sedimentation rate of $0.08 \mathrm{~cm} \mathrm{yr}^{-1}$ between $1920-1960$ and a rate of ca. $0.2 \mathrm{~cm} \mathrm{yr}^{-1}$ after 1960 .

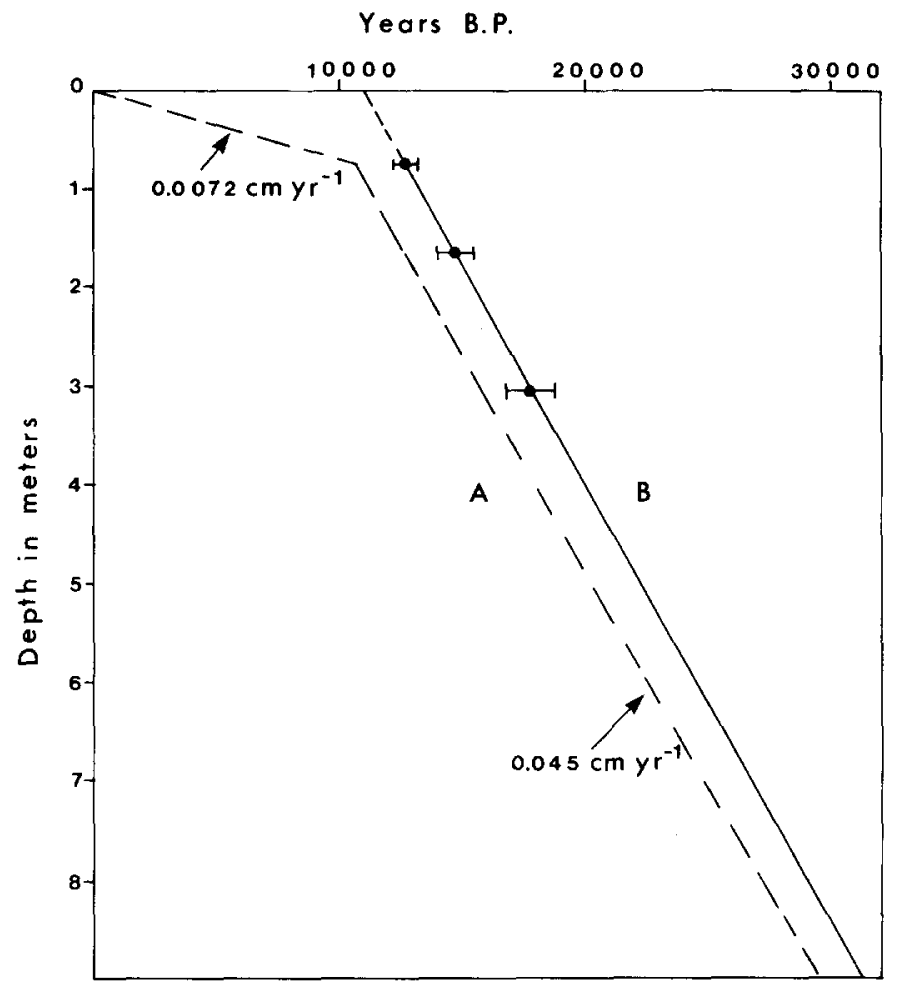

Fig.2. Regression line for ${ }^{14} \mathrm{C}$-dates $\left({ }^{14} \mathrm{C}\right.$ counting error) for Core 9. $A=$ corrected regression line; $B=$ uncorrected regression line. 
The mean of three surface sediment samples (E.E. Kopczynska, personal communication, 1974; Fig.1) taken within $3 \mathrm{~km}$ of Core 9 shows a different percent relative abundance of valves from samples from the top of the core. In the surface sediment samples (mean total number of valves $=432 \pm 4$ ) the percent relative abundance was Cyclotella ocellata $65 \%, C$. fottii $22 \%$, and C. kutzingiana $12 \%$, in Core $9(0 \mathrm{~cm}$, total valves $=441)$ C. complex $30 \%$, Stephanodiscus sp.1 (cf. S. hantzschii) 24\%, C. sp.1 15\%, and C. ocellata $9 \%$. Lead-210 dating of the top of Core 9 would aid in the explanation of these discrepancies.

\section{Chemical profile}

Sediment moisture (Fig.3) varies between 50 and $60 \%$ of wet weight. The low value at $340-350 \mathrm{~cm}$ is the result of the sediment drying out. A $4-\mathrm{cm}$ band of sand between $697-701 \mathrm{~cm}$ resulted in the low value at $700 \mathrm{~cm}$. The sand grains at $700 \mathrm{~cm}$ are long (ca. 200-400 $\mu \mathrm{m}$ ) with shear lines and are probably loess. The organic content (Fig.3) varies between 2 and $3 \%$ of total weight $(\bar{x}=-2.73 \pm 0.39)$. The $\mathrm{CaCO}_{3}$ content (Fig.3) from $885-110 \mathrm{~cm}$ also varies between 2 and $3 \%(\bar{x}=2.32 \pm 0.55 \%$ of total weight) but increased in the top meter of the core ( $\bar{x}=11.03 \pm 8.86 \%$ of total weight).

\section{Diatom profile}

The diatom profile of Core 9 is shown in Fig.4. Like many deep oligotrophic lakes (e.g., Lake Superior, Schelske et al., 1972; Lake Biwa, Mori and Horie, 1975; Lake Baikal, Chernyaeva, 1970), Lake Ohrid is dominated by a group of centric diatoms. Hustedt (1945), who sampled this lake mainly in the littoral zone and Jurilj (1954), who sampled the benthic zone, recorded 355 species and varieties, representing 40 genera. Among these species 75 were new records and many are considered endemics.

The 62 species found in the core can be divided into five groups (Table I) according to the regions in which they were found (Fig.5). Group I consists of seven species distributed throughout the entire core $(885-0 \mathrm{~cm})$. Cyclotella fottii, a prominent member of Group I, may also be a relict species as it closely resembles the fossil $C$. iris Brun found in the Neogene layers of Aurillac, France (Stanković, 1960).

Three Cyclotella forms of Group I (C. fottii 40-90 $\mu \mathrm{m}$, C. hustedtii 20$30 \mu \mathrm{m}, C$. hustedtii var.1 10-20 $\mu \mathrm{m}$ ) were designated as the "Cyclotella complex" because they were all found throughout the core, appeared to respond to changes as a unit (Fig.6), and were morphologically similar. This Cyclotella complex strongly dominated the core.

Although the species diversity index (Shannon and Weaver, 1949) is not particularly useful throughout most of the core, it clearly shows how often the Cyclotella complex, marked by dots, was the only diatom assemblage found in the sampled intervals (Fig.7). 


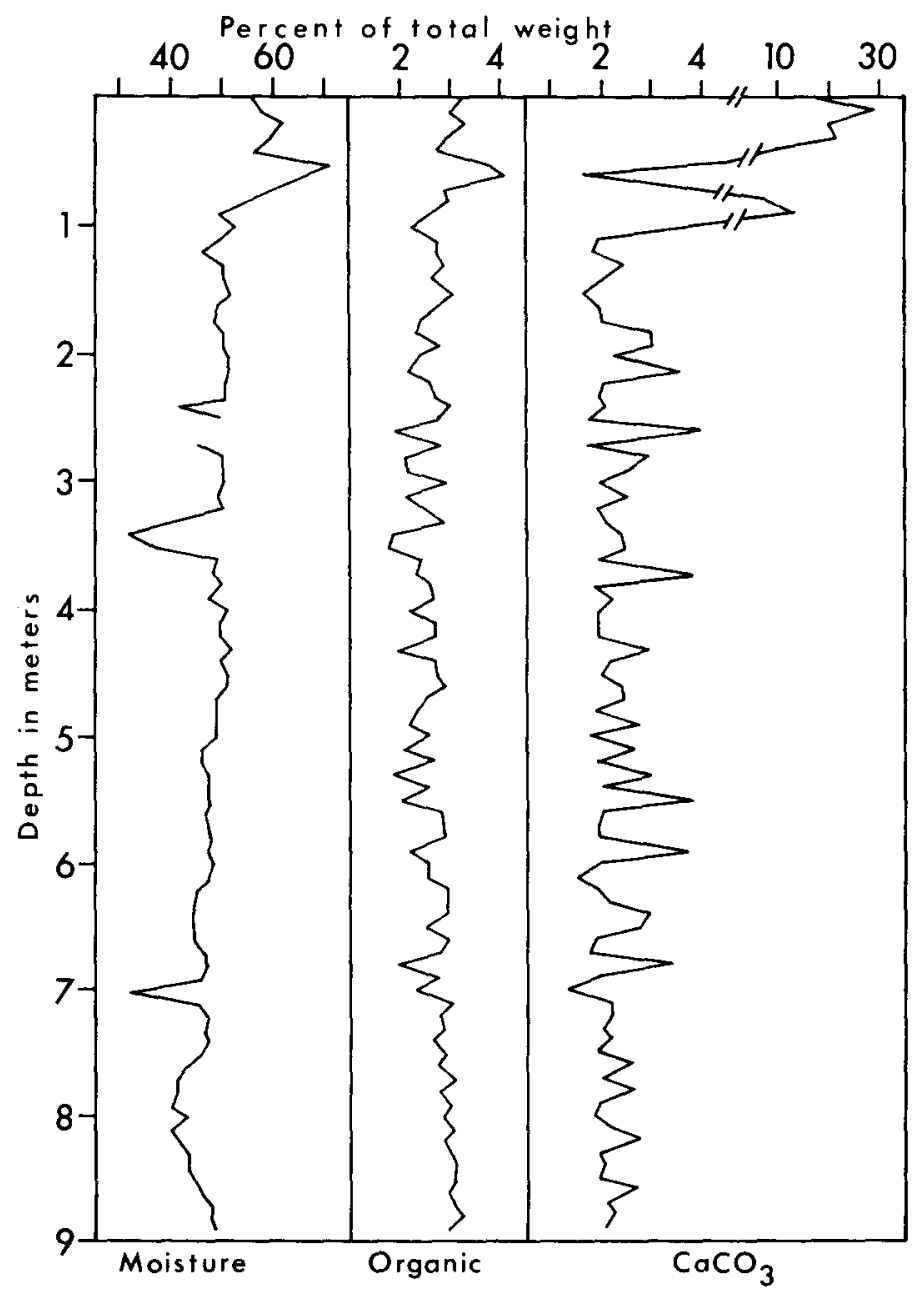

Fig. 3. Moisture, organic, and $\mathrm{CaCO}_{3}$ content as a percent of total weight. Datum point is missing for moisture content at $260 \mathrm{~cm}$.

Group II is the largest group in terms of number of species (26) and was found only between $100-0 \mathrm{~cm}$. Cyclotella stelligera is the only exception, in that it was also found at $260 \mathrm{~cm}$. A fossil C. kutzingiana (Schmidt, 18741927) was found at $0 \mathrm{~cm}$ and has not been previously reported for the Balkan region.

A more detailed study was made of the core samples at $190,450,600$, and $800 \mathrm{~cm}$ to determine if any of the species from Group II (which appeared to be restricted to the zone from $100-0 \mathrm{~cm}$ ) would be found if a larger sample (ca. 18 times the usual area) was counted. More species were indeed found, but the results were not significantly different from the original counts, and only one species (Cymbella microcephala) from Group II was found as a result of this more intensive survey. 


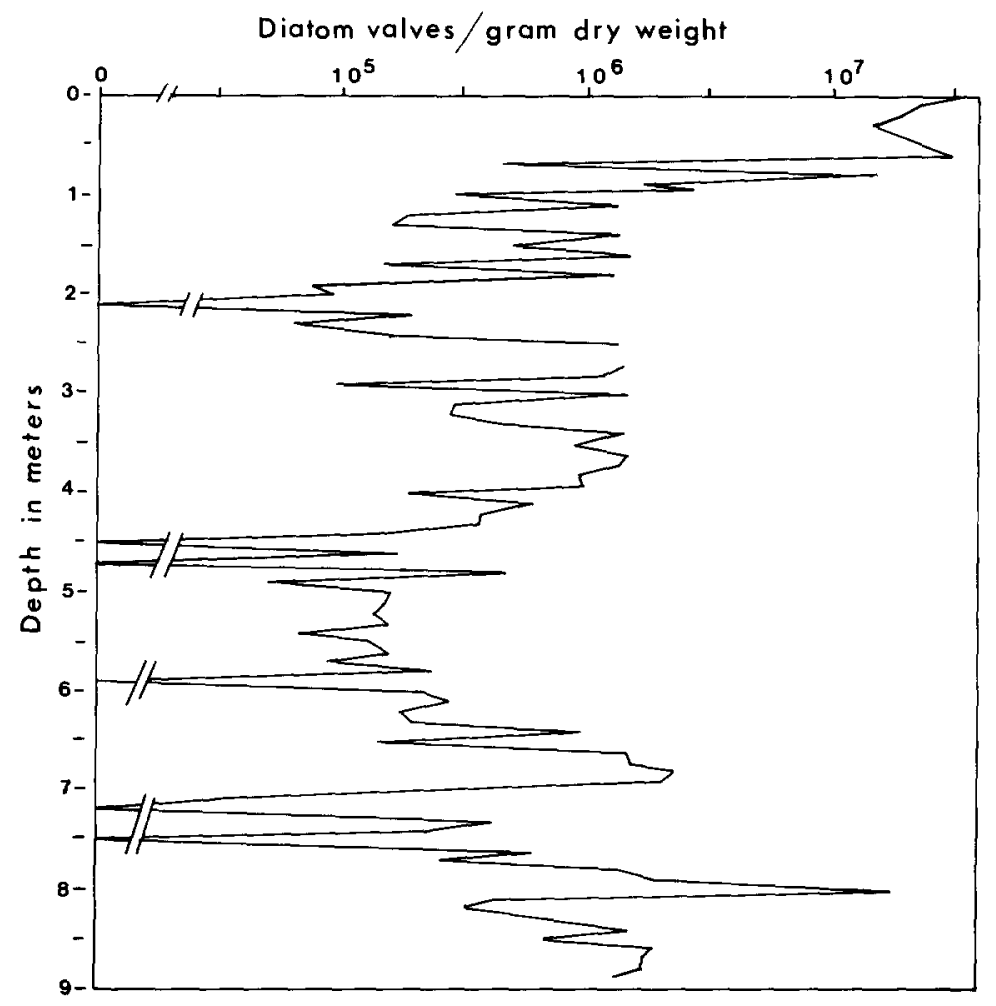

Fig.4. Diatom profile for Core 9. Datum point is missing at $260 \mathrm{~cm}$.

Group III consists of five littoral species found only between $630-110 \mathrm{~cm}$. All but Achnanthes fonticolla have been recorded for the modern flora (Hustedt, 1945; Jurilj, 1954). Achnanthes fonticolla is recorded as a new species for the headwaters of the Krka near Laibach in the Balkan region (Hustedt, 1945). The abundance of this group is very low with the majority of occurrences between $360-300 \mathrm{~cm}$.

Group IV consists of twelve species found only between $885-640 \mathrm{~cm}$. Diploneis (Navicula) budayana is considered to be a relict species of the Tertiary (Jurilj, 1954).

Group V consists of twelve species found in two regions: from 885$630 \mathrm{~cm}$ and from $270-0 \mathrm{~cm}$. Cyclotella sp.1 and 2 are very small forms, 2-6 $\mu \mathrm{m}$ and 5-10 $\mu \mathrm{m}$ respectively. Navicula balcanica is considered a Balkan endemic (Hustedt, 1945). 


\section{TABLE I}

List of species in groups (see Fig.5)

Group I (0-885 cm)

Cocconeis disculus (Schum.) Cl. $\mathrm{LO}^{1}$

Cyclotella fottii Hust. PO

Cyclotella hustedtii Jur. PO

Cyclotella hustedtii var. 1

Fragilaria construens (Ehr.) Grun. LO

Fragilaria pinnata Ehr. LO

Opephora martyi Herib. LO

Group II $(0-100 \mathrm{~cm})$

Asterionella formosa Hass. PO

Cyclotella kïtzingiana Chauvin (fossil)

Cyclotella sp. 3

Cyclotella stelligera (Cl. and Grun.) V.H. PO

Cymbella microcephala Grun. LO

Cymbella prostata (Berk.) Cl. LO

Denticula elegans Kütz.

Diatoma vulgare v. grandis (W.Sm.) Grun. LO

Epithemia lunata v. obesa Jur. LO

Epithemia turgida (Ehr.) Kütz. LO

Epithemia zebra (Ehr.) Kiitz. LO

Fragilaria crotonensis Kitton PO

Fragilaria leptostauron (Ehr.) Hust. LO

Fragilaria leptostauron v. dubia (Grun.) Hust. L

Gomphonema intricatum v, pumila Grun. LO

Navicula bacillum Ehr. LO

Navicula modica Hust. LO

Navicula placentula (Ehr.) Kütz. LO

Navicula stankovici Hust. LO

Nitzschia filiformis (W.Sm.) Schutt

Nitzschia gracilis Hantz. LB

Nitzschia kiutzingiana Hilse LO

Stephanodiscus astraea v. intermedia Fricke PO

Stephanodiscus astraea $v$. intermedia f. 1

Stephanodiscus sp. 1

Synedra acus Kütz. LO
Group III (110-630 cm)

Achnanthes fonticola Hust. LB

Amphipleura sp. 1

Diplone is domblittensis (Grun.) Cl. LO

Fragilaria construens v. venter (Ehr.) Grun. LO

Pinnularia borealis Ehr. LO

Group IV (640-885 cm)

Achnanthes biasolettiana (Kütz.) Grun.

A chnanthes oestrupi (A.Cl.) Hust. LB

A chnanthes ploenensis Hust.

A mphora perpusilla (Grun.) Grun.

Coccone is diminuta Pant. LO

Diatoma vulgare v. brevis Grun. LO

Diatoma vulgare v. ovalis Grun. LO

Diploneis (Navicula) budayana (Pant.) Jur. O

Diplone is mauleri (Brun.) Cl. LO

Gomphonema olivaceum (Lyngb.) Kütz. LO

Navicula (A chnanthes) sp. 1

Synedra vaucheriae $\mathrm{K}$ ütz. LO

Group V $(0-270$ and $630-885 \mathrm{~cm})$

Achnanthes clevei Grun. LO

Achnanthes conspicua A. Mayer LO

A mphora ovalis v. pediculus (Kütz.) V.H. LO

Cyclotella ocellata Pant. PLO

Cyclotella sp. (aff. kützingiana)

Cyclotella sp. 1

Cyclotella sp. 2

Diploneis elliptica (Kütz.) Cl. LO

Frustulia rhomboides v, saxonica (Rabh.) DeT. LB

Navicula anglica Ralfs LO

Navicula balcanica Hust. PLO

Staurone is smithii v, incisa Patr. LO

${ }^{1} \mathrm{P}=$ planktonic species; $\mathrm{L}=$ littoral species $; \mathrm{O}=$ species previously reported for Lake Ohrid; $B=$ species previously reported for the Balkan region.

\section{DISCUSSION}

\section{Dating the core}

Providing an entirely satisfactory interpretation of the radiocarbon dates obtained for Core 9 is not yet possible. However, we currently believe that the core represents ca. 30,000 yr of lacustrine history. This estimate is based on the results of pollen analyses done on sediments from the core by W. A. Watts (personal communication, 1981), ${ }^{14} \mathrm{C}$-dates, and the stratigraphic patterns found for Cladocerans (L. Frey, personal communication, 1979) and diatoms.

Extrapolation of the regression line for the uncorrected ${ }^{14} \mathrm{C}$-dates for Core 9 (Fig. 2 and Results) to the surface of the sediment gives an unusually large 


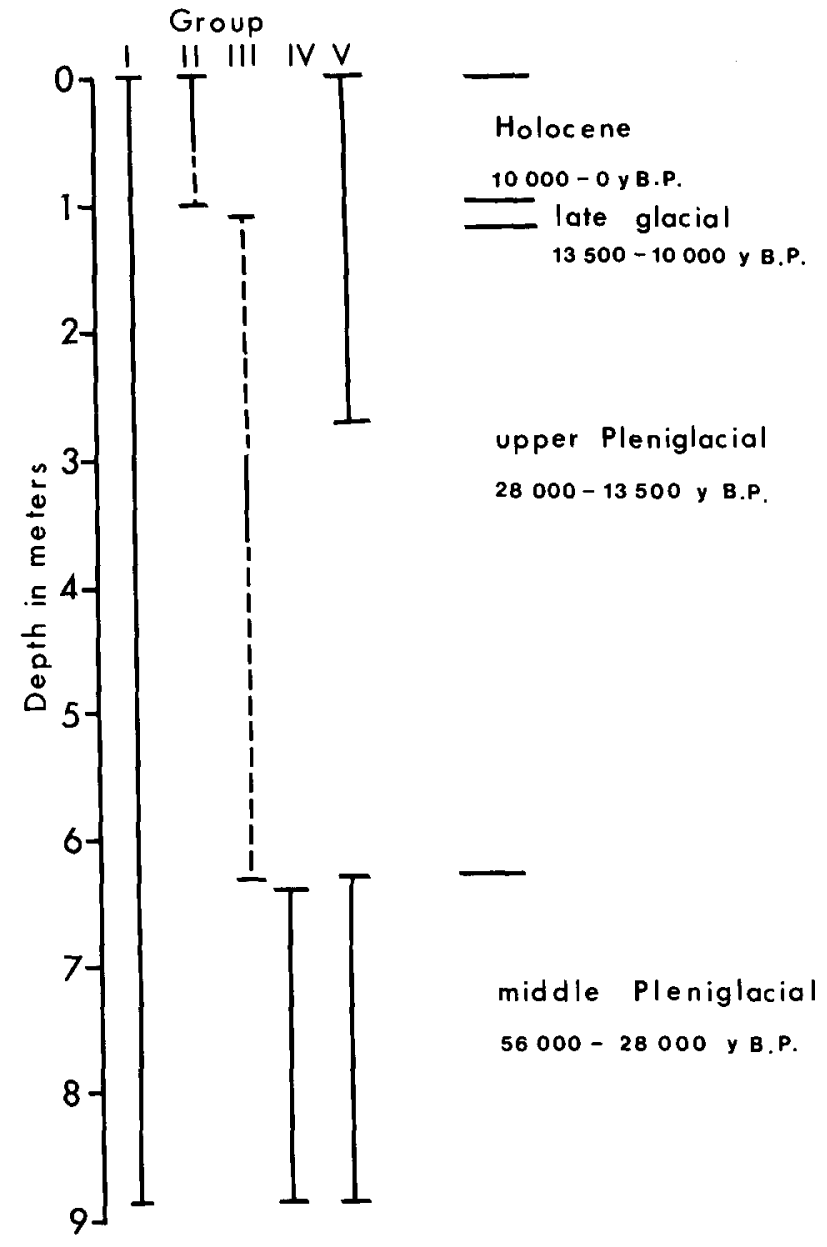

Fig.5. Distribution of diatom groups (see Table I) with stratigraphic units and corresponding dates.

surface age of $11,042 \mathrm{yr}$ B.P. We have identified three potential explanations for this large age discrepancy:

(1) The surface sediments are in reality ca. $11,000 \mathrm{yr}$ old. In this case, all the sediments of more recent age have been eroded away by some unknown process.

(2) The large finite surface is an artifact resulting from ${ }^{14} \mathrm{C}$-deficiency in the dissolved inorganic carbon pool of the lake. ${ }^{14} \mathrm{C}$-deficiency is generally observed in waters that have leached ancient calcareous rocks (Deevey et al., 1954; Broecker and Walton, 1959) containing little if any ${ }^{14} \mathrm{C}$. The most prevalent rocks in the drainage basin of Lake Ohrid are Triassic limestones (Ivanovski and Stračkov, 1974). 


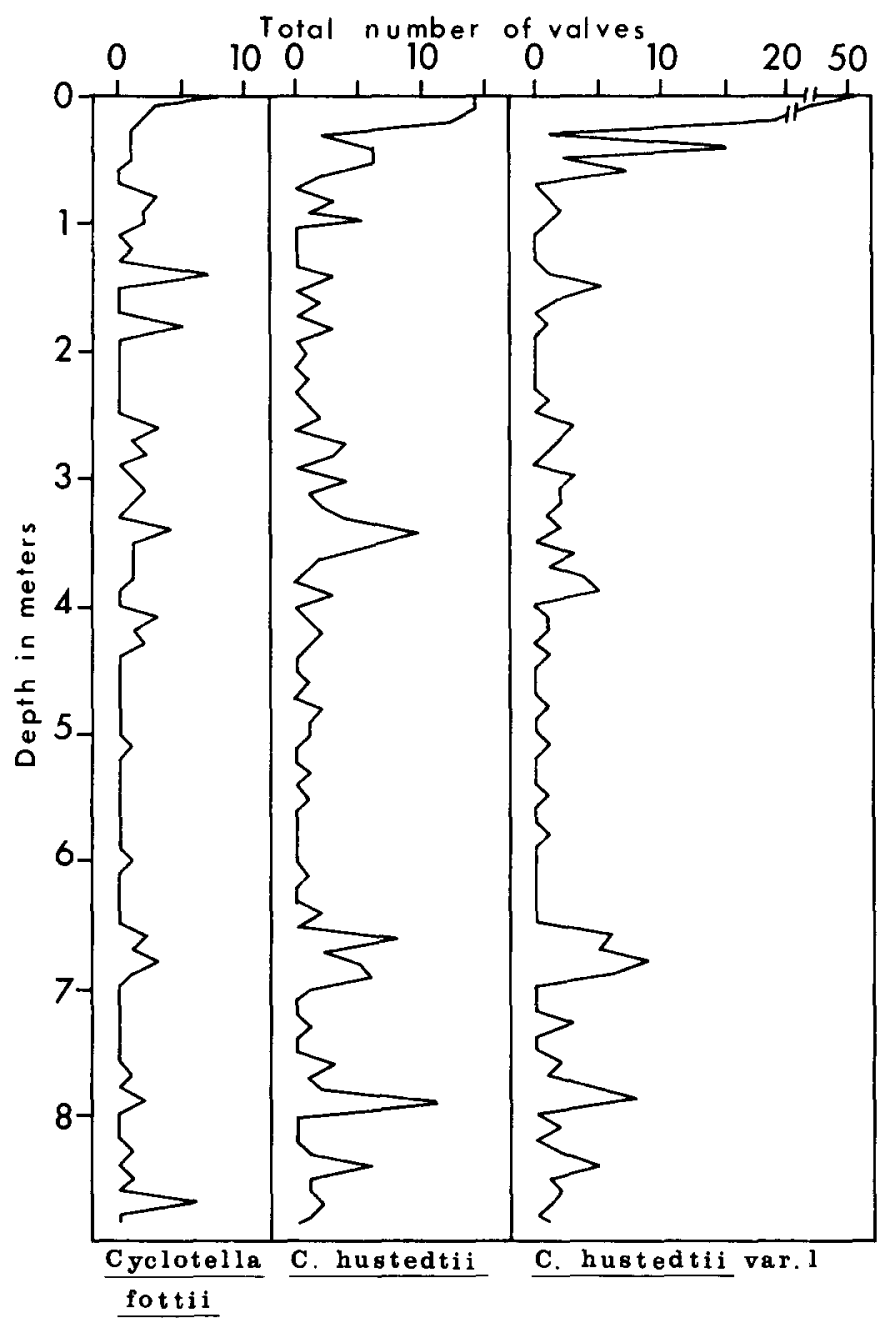

Fig.6. Stratigraphic distribution of the Cyclotella complex.

(3) A major change (decrease) in sedimentation rate occurred above 80$76 \mathrm{~cm}$ in the core. Therefore, the regression line for the uncorrected dates cannot be legitimately extrapolated to the surface of the sediments.

If one were to attempt to date the core using only the stratigraphic information obtained for the microfossils, one would conclude that the top meter of the core contains an unbroken sedimentary record for the entire Holocene. Comparisons of the pollen stratigraphy of the core with pollen diagrams available for other localities in Macedonia (Ioannina, Bottema, 1967; Philippi, Wijmstra, 1969) indicate that the Holocene/late glacial boundary (ca. 10,000 yr B.P.) occurs within the first meter of the core. This boundary is characterized by a sharp rise in the percentages of Artemisia and Chenopodiaceae 


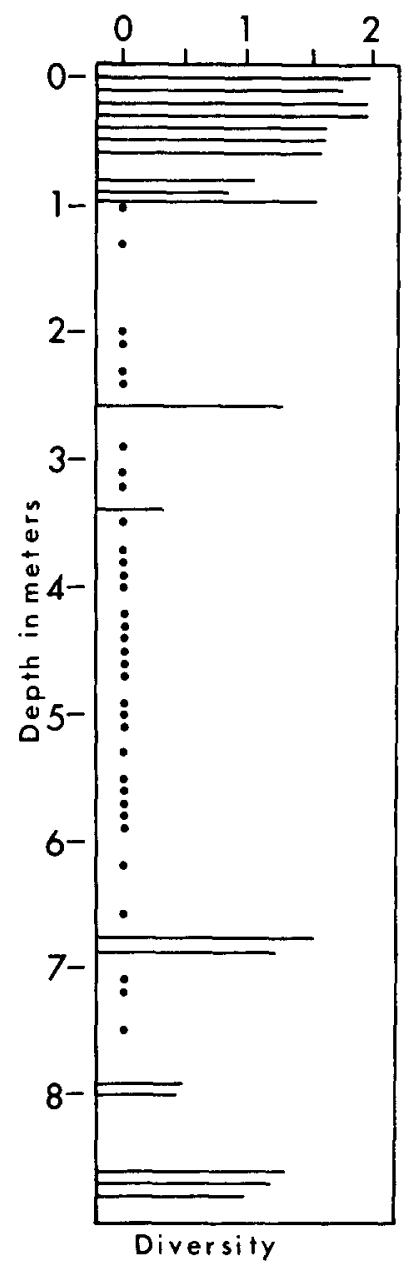

Fig.7. Diversity for intervals with a total count of greater than twenty valves. Dots indicate intervals where the Cyclotella complex was the only species found.

pollen. These observations concerning the location of the Holocene/late glacial boundary in the core provide little support for the first two potential explanations. If the first explanation were correct, the Holocene/late glacial boundary would not be present in the core at all and if the second explanation were correct this boundary should be found at ca. $5 \mathrm{~m}$ (assuming that one could correct for ${ }^{14} \mathrm{C}$-deficiency by simply sliding the regression line for the ${ }^{14} \mathrm{C}$-dates over to the left in Fig.2 until it went through the origin). Explanation two has an additional problem in that a ${ }^{14} \mathrm{C}$-deficiency of $11,000 \mathrm{yr}$ is 5 -times larger than any ${ }^{14} \mathrm{C}$-deficiency ever reported. For theoretical reasons, ${ }^{14} \mathrm{C}$-deficiencies are generally less than $2000 \mathrm{yr}$ (Broecker and Walton, 1959). However, theoretical calculations of maximum ${ }^{14} \mathrm{C}$-deficiency 
assume that all the $\mathrm{CO}_{2}$ involved in the leaching of ancient calcareous rocks is of recent atmospheric origin. If this were not the case, owing to the recycling of ancient carbon by biota in the system, ${ }^{14} \mathrm{C}$-deficiencies even higher than those currently considered possibly might occur.

Our interpretation of the age B.P.--sediment depth relationship for Core 9 is shown (see dashed line) in Fig.2. To obtain this line we first corrected for ${ }^{14} \mathrm{C}$-deficiency by subtracting 2000 yr (the maximum age discrepancy commonly observed as a result of ${ }^{14} \mathrm{C}$-deficiency; Broecker and Walton, 1959) from each of the uncorrected ${ }^{14} \mathrm{C}$-dates. Therefore, our corrected age - depth relationship (Fig.2, line $A$ ) for Core 9 gives minimum values for each date $( \pm$ the counting error). The actual dates lie somewhere between the corrected (line $A$ ) and uncorrected (line $B$ ) regression lines. All of the dates presented in this paper were obtained from the corrected regression line. We then drew a line from the corrected ${ }^{14} \mathrm{C}$-date for $80-76 \mathrm{~cm}(10,765$ yr B.P.) through the origin $(0 \mathrm{~cm}, 0 \mathrm{yr}$ B.P. or 1950 A.D.). This interpretation of the agedepth relationship gives a sedimentation rate of $0.045 \mathrm{~cm} \mathrm{yr}^{-1}$ prior to ca. $10,000 \mathrm{yr}$ B.P. and a rate of $0.0072 \mathrm{~cm} \mathrm{yr}^{-1}$ since that time.

How plausible is our proposed 6 -fold decrease in sedimentation rate for the Holocene? During the late glacial when the climate in this part of Europe was cooler and drier than it is at present (Van der Hammen et al., 1971), Lake Ohrid was probably a typical dimictic lake; but at the beginning of the Holocene, when the climate became warmer and wetter, it is quite likely that the lake became oligomictic, as it remains to this day. Such a change in mixing regime can have a pronounced effect on sedimentation rates.

Sediment focusing is the process by which sediments are directed toward the deepest part of a lake basin (Lehman, 1975). This occurs as a consequence of mixing. Sediments may be initially deposited fairly evenly over the lake basin, but when mixing occurs shallow-water sediments are resuspended more extensively than sediments from deep water. Thus a net movement of sediments occurs from shallow to deep water (Davis and Brubaker, 1973). It is therefore reasonable to suspect that the process of sediment focusing produced considerably higher rates of sedimentation at the Core 9 site when the lake was dimictic than it has since the lake became oligomictic. It is also conceivable that the loading of sedimentary material to the lake basin has decreased since the late glacial when rates of mechanical weathering in the mountains may have been higher than they are at present. Such a decrease in sediment loading would also decrease the rate of sediment accumulation throughout the lake basin.

The higher rates of sedimentation computed from ${ }^{210} \mathrm{~Pb}$-dates (i.e., 0.08 and $0.2 \mathrm{~cm} \mathrm{yr}^{-1}$ ) for a surface core taken near the Core 9 site probably reflect higher sedimentation rates brought about by man's recent activities in the drainage basin (Robbins, 1978). Since the beginning of the century, the population of this region has increased markedly and the Sateska River that formerly flowed to the north of the lake now flows into it.

The sedimentary record of Core 9 appears to be complete and unbroken. The ${ }^{210} \mathrm{~Pb}$-dates indicate that the surface sediments are intact. The pollen 
stratigraphy determined for cores from other localities in Macedonia, and the Holocene/late glacial boundary (ca. 10,000 yr B.P.) occurs within the first meter of the core. Because our ${ }^{14} \mathrm{C}$-dates fall on a straight line (Fig.2), breaks in the sedimentary record between the first and third meters of the core are unlikely. Except for the band of sand between $697-701 \mathrm{~cm}$, Core 9 is very homogeneous from $110 \mathrm{~cm}$ to the bottom $(885 \mathrm{~cm})$. There is little variation in the content of moisture, organic matter, and $\mathrm{CaCO}_{3}$. If breaks in the sedimentary record have occurred, they are not reflected in the pollen stratigraphy, ${ }^{14} \mathrm{C}$-dating, or the chemistry of the core.

\section{Diatom stratigraphy}

The $8.85 \mathrm{~m}$ Core 9 represents a period of ca. 30,000 yr, covering half of the Pleniglacial, the late glacial, and the Holocene. A very distinct floristic difference exists between the diatom assemblages above and below $60 \mathrm{~cm}$. Below $60 \mathrm{~cm}$ (i.e., below the Holocene/late glacial boundary), the Cyclotella complex was almost always dominant and the total number of valves at each sampling interval was low. The peaks in number of valves and species diversity in the assemblages at $885-630 \mathrm{~cm}, 360-300 \mathrm{~cm}$, and $110-80 \mathrm{~cm}$ were probably the result of the amelioration of the climate over these periods.

The Pleniglacial (ca. 60,000-13,500 yr B.P.) can be split into three intervals: the upper, middle, and lower. There were glacial advances during the upper and lower Pleniglacial and the climate seems to have been generally colder and less humid than during the middle Pleniglacial (Van der Hammen et al., 1971). The ice sheet did not reach the Ohrid area but local glaciers formed (Stanković, 1960). There were no interstadials in the lower Pleniglacial, six in the middle, and two in the upper Pleniglacial (Wijmstra, 1969).

The five littoral species of Group III $(630-110 \mathrm{~cm})$ occur at seven intervals in the core with the majority between $360-300 \mathrm{~cm}$ which corresponds with the slight warming of the Philippi interstadial during the cold upper Pleniglacial. A more pronounced increase in numbers and species occurs between $885-630 \mathrm{~cm}$ which corresponds with the beginning of the warmer, more humid middle Pleniglacial. Of the twelve species of Group IV $(885-630 \mathrm{~cm})$ five are not recorded in the modern flora; these may not have survived the Glacial Age in Lake Ohrid.

Amelioration of the upper Pleniglacial climate seems to have begun between 14,000-13,000 B.P., which marks the boundary with the late glacial during which the ice sheet retreated to central Sweden (West, 1968). In pollen diagrams from Philippi, northeastern Greece (Wijmstra, 1969) and Ioannina, northwestern Greece (Bottema, 1967), ca. $300 \mathrm{~km}$ east and $100 \mathrm{~km}$ south of Lake Ohrid respectively, the late glacial exhibits a sharp floral peak. Between 110-70 cm, which corresponds to the late glacial, an analogous diatom peak occurs. Climate diagrams for northwest Europe indicate fluctuations from sub-arctic through boreal to cool temperature climate, back to sub-arctic during the Aller $\phi \mathrm{d}$ (Xanthi) interstadial. This was followed by the 
warm temperate climate of the Holocene (West, 1968). In the Philippi pollen diagram this climatic fluctuation is evidenced by a change from the open Artemisia/Chenopodiaceae vegetation of the cold upper Pleniglacial, through an open oak forest, back to an Artemisia/Chenopodiaceae vegetation at the late glacial/Holocene boundary. The effect of this short (ca. $600 \mathrm{yr}$ ) cold period before the Holocene is represented in the diatom diagram by a marked decrease in valve numbers from 141 at $80 \mathrm{~cm}$, to 5 at $70 \mathrm{~cm}$, followed by a marked increase at $60 \mathrm{~cm}$ ( 298 valves).

An analysis of the top $230 \mathrm{~cm}$ of Core $9(10 \mathrm{~cm}$ intervals) for zooplankton (L. Frey, personal communication, 1979) shows a similar pattern but one which lags behind the changes in numbers of diatoms. Bosmina, the most abundant Cladoceran in the sediment, first occurs at $100 \mathrm{~cm}$. There are also low numbers of microfossils (less than 1000 per $\mathrm{cm}^{3}$ of sediment at 80 and $70 \mathrm{~cm}$ ). At $60 \mathrm{~cm}$, where the diatom numbers increase, there are no zooplankton remains; but at $50 \mathrm{~cm}$ there are greater than 10,000 microfossils/cc of sediment.

The Cyclotella complex is dominant throughout the core except at six intervals $(40,50,80,800,860$, and $880 \mathrm{~cm})$, all of which are dominated by Cyclotella sp. 1 which is the major member of Group V $(885-630 \mathrm{~cm}$ and 270-0 cm). Cyclotella sp.1 and C. ocellata, like the Cyclotella complex, seem to respond as a unit (Fig.8). The Cyclotella complex and Cyclotella sp.1/C. ocellata tend to alternate, so that when one is dominant, the other declines (Fig.9). The occurrences of Group V species during warmer periods (below 630 and $110-80 \mathrm{~cm}$ ) and their disappearance between $620-280 \mathrm{~cm}$ is possibly related to climate.

Cyclotella fottii (Group I) is found throughout the year in the Lake Ohrid phytoplankton with significant populations between $50-200 \mathrm{~m}$; it is also a dominant of the spring bloom between $0-200 \mathrm{~m}$ (Kozarov, 1954). The annual cycle of $C$. fottii shows an inverse relationship between temperature and cells/liter (Kozarov, 1954).

Throughout the core there is an inverse relationship between organic and $\mathrm{CaCO}_{3}$ content (Fig.3). The basis for the relationship is the scavenging effect of $\mathrm{CaCO}_{3}$ discussed above. The similarity of the diatom assemblages between $100-80 \mathrm{~cm}$ and below $630 \mathrm{~cm}$ indicates that the marked inverse chemical relationship between $110-70 \mathrm{~cm}$ is likely the result of a natural influx of nutrients and/or carbonates owing to increased precipitation. However, the inverse chemical relationship at $60 \mathrm{~cm}$, the influx of Group II species, and the large increase in valves/gram dry weight indicate eutrophication, in the classical sense of increased supplies of nutrients beyond what would have occurred naturally. A similar inverse relationship between $\mathrm{CaCO}_{3}$ and organic content was found for core samples from Lawrence Lake Michigan (Wetzel and Manny, 1978). This was interpreted as evidence of a settlement horizon.

Archaeological evidence establishes human occupation of Yugoslavia in the Lower Paleolithic Period (the Riss glaciation, ca. 200,000-100,000 yr B.P.) (Alexander, 1972). The Paleolithic inhabitants were a cave-dwelling, 


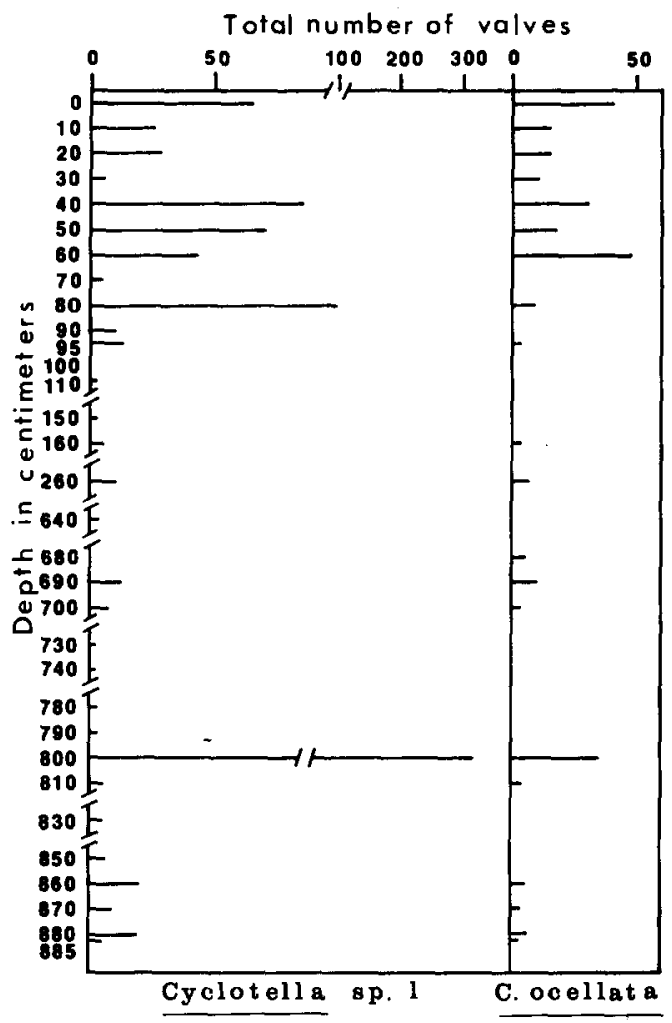

Fig.8. Stratigraphic distribution of Cyclotella sp.1 and C. ocellata.

Old Stone Age, hunter/gatherer/fisher people who would have had little or no effect on the lake's ecology.

Early experiments in cultivation and domestication began in the Middle Stone Age or Mesolithic (early Holocene, ca. 10,000-8000 yr B.P.). The Bitolj Culture flourished in the Lake Ohrid area during the Copper Age or Middle Neolithic (ca. 8000-5000 yr B.P.). A dynastic cemetery, of the ironusing Trebeniste Culture (Late Bronze Age, ca. 2600 yr B.P.), has been found at Trebeniste on the north shore of Lake Ohrid (Alexander, 1972). By the Early Iron Age (350-11 B.C.) the tribes along the southern frontier between Macedonia and Greece established fortified settlements. In 360 B.C., Bardylis, ruler of the Lyncus region beside Lake Ohrid, overran much of Greek Macedonia but was driven back a few years later by Philip II, Alexander the Great's father. Bardylis' successor was defeated in either Philip and Alexander's 346-343 B.C. or Alexander's 335 B.C. northern expeditions (Philip was assassinated in 336 B.C.). Alexander established the first known town in the region, Aerachia Lynci (Ohrid town) (Alexander, 1972).

Because the sedimentation rates are probably not constant above $70 \mathrm{~cm}$, there can be no accurate interval correlation with the Bitolj and Trebeniste 


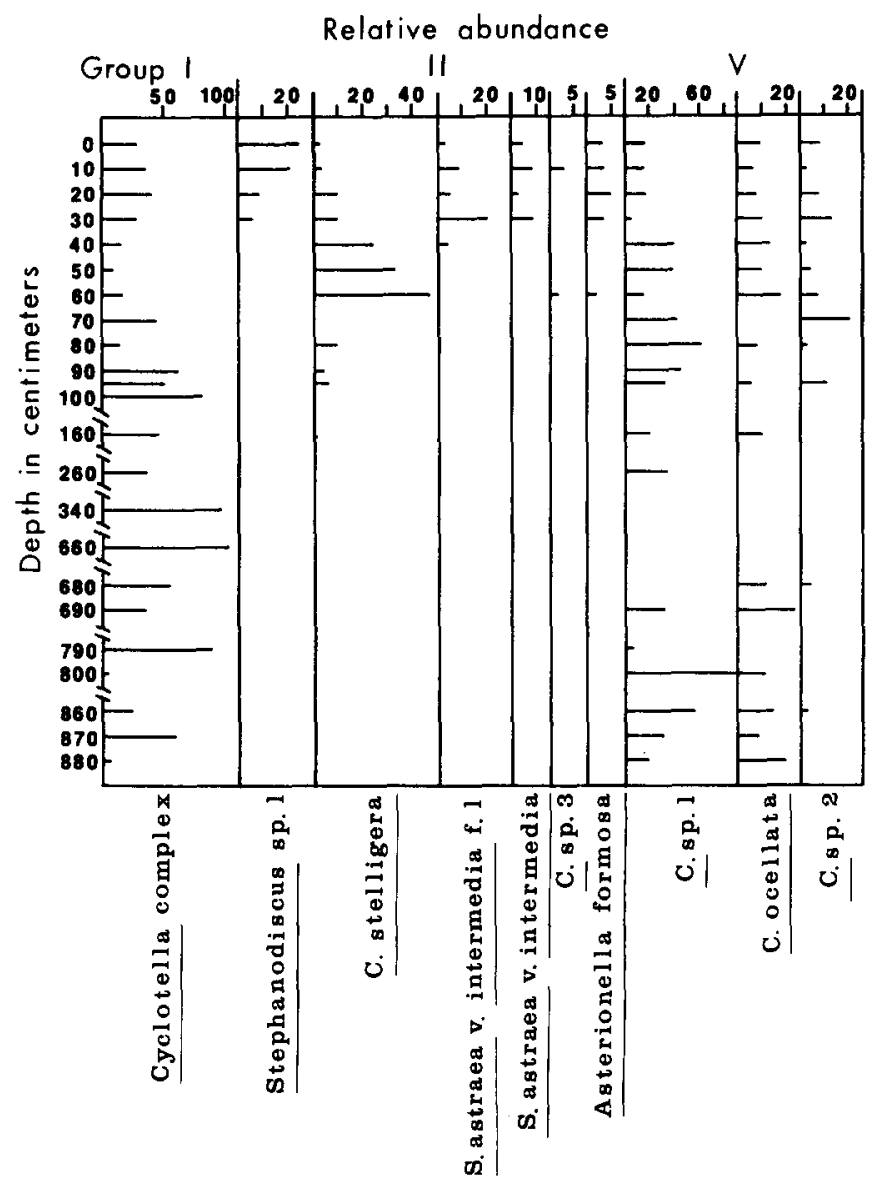

Fig.9. Relative abundance of dominant and subdominant species in Core 9.

Cultures or Alexander's Aerachia Lynci. However, there is evidence that these influences have led to eutrophication. Deforestation and farming, which would have caused an increased influx of carbonates and nutrients, is the probable cause of the changes above $70 \mathrm{~cm}$.

Stockner and Benson (1967) used an Araphidineae/Centrales index for Lake Washington (Washington, U.S.A.) as a measure of cultural eutrophication. Their reasoning was that Centrales as a group achieved their greatest diversity in oligotrophic waters and that mesotrophic-eutrophic waters had a greater proportion of Araphidineae. As Cyclotella species are predominate in Lake Ohrid and the frequency of Araphidineae is very low, the $\mathrm{A} / \mathrm{C}$ index is always less than 1.0, an indication of an oligotrophic lake (Stockner, 1971). There are eleven Araphidineae in the core. Three are in Group I, six in Group II, one each in Groups III and IV, and none in Group V. Of the six in Group II, Asterionella formosa, Synedra acus, and Fragilaria crotonensis are regarded 
as araphidinate species in Stockner's (1971) A/C index. Although their absolute abundance is still very low in the Lake Ohrid core, there is a small but steady increase between $100-30 \mathrm{~cm}$ and a more pronounced increase above $30 \mathrm{~cm}$, perhaps indicating a degree of eutrophication.

Brugam (1979) working in Minnesota (U.S.A.) found that Stephanodiscus hantzschii can be used as an indicator of increasing nutrient input in lakes with high alkalinity, whereas the $\mathrm{A} / \mathrm{C}$ index is more efficient in low alkalinity lakes. Lake Ohrid is a karstic lake and S. sp.1 (cf. S. hantzschii) is a co-dominant in surface sediments with the Cyclotella complex. S. hantzschii has also been identified as one of the dominants of the spring bloom in Ohrid (Stanković, 1960).

Various factors may explain the origin of the immigrant species of Group II and the reappearance of Group V; two possible explanations are: (1) cultural and natural introduction and/or (2) introduction via the subterranean connection with Lake Prespa. Cultural effects are more likely to act through an increase in nutrient input rather than through actual introduction of species. Another possibility is that eels which migrate up the Drim River from the Adriatic Sea (Jurilj, 1954) and other immigrant animals in Lake Ohrid may have been responsible for introducing diatoms (Stanković, 1960).

Stanković (1960) believes there may be a subterranean connection between Lake Ohrid and Lake Prespa (158 $\mathrm{m}$ higher and $16 \mathrm{~km}$ to the east) through the calcareous strata of the Galicica Range. If this is true, Lake Prespa may have been a refuge for many of the new or re-introduced species in Lake Ohrid. A comparison of the species lists (Hustedt, 1945) shows that $85 \%$ of Lake Prespa's diatoms are also found in Lake Ohrid.

Although Lake Ohrid is more productive now than it was below $60 \mathrm{~cm}$, the increased influx of nutrients which may have allowed the increase in diatom diversity and numbers is also a factor in the suppression of total phytoplankton production. Increased stimulation of photosynthesis in the littoral zone may reduce the overall availability to the phytoplankton of inorganic and organic nutrients owing to their co-precipitation with $\mathrm{CaCO}_{3}$.

At present the factors controlling the diatom populations in Lake Ohrid are poorly known, but stratification, temperature, transparency, light intensity, $\mathrm{CaCO}_{3}$ dynamics, low bacterial activity, and the rate of influx of nutrients are among them (Allen and Ocevski, 1976). Assuming that the present-day suppressive mechanisms were functioning similarly below $60 \mathrm{~cm}$, it is unlikely that a change in climate alone could explain the differences above $60 \mathrm{~cm}$. Some of the species in Group II $(100-0 \mathrm{~cm})$ can tolerate low temperatures and oligotrophic conditions. It appears that below $60 \mathrm{~cm}$ nutrients were not plentiful enough or in the right proportions to support the species of Group II because their occurrence coincides with the increased nutrient supply resulting from cultural eutrophication.

None of the species in Group I $(885-0 \mathrm{~cm})$ have decreased in number and although the Cyclotella complex has a lower relative abundance above $60 \mathrm{~cm}$, it has a higher absolute abundance. Allen and Ocevski's (1976) study showed 
that many nutrients are probably limiting in the hypolimnion, yet $C$. fottii maintains significant populations there. However, in Lake Ohrid, the Cyclotella complex and many of the endemic species evolved in an environment of limitations. Their continued existence and increase above $60 \mathrm{~cm}$ and the increased species diversity in the upper layers of the core indicate that resources in the present environment are not yet inhibiting.

\section{ACKNOWLEDGEMENTS}

We wish to thank Drs. W. S. Benninghoff, S. S. Kilham, and E. F. Stoermer for their assistance and encouragement of this study. The assistance of the Foreign Currency Program, Office of Intermational and Environmental Activities, Smithsonian Institution (Grant SFG-2-8264) is gratefully acknowledged. Our laboratory research was supported by National Science Foundation Grants OCE-76-10183 and OCE-78-27016 from the Oceanography Section to Drs. P. and S. S. Kilham. This was prepared while A. K. Roelofs was supported by National Science Engineering Research Council of Canada Grant A-6137 to Dr.F. J. R. Taylor. This study would not have been possible without the help and encouragement of the scientists and staff of the Hydrobiological Institute, Ohrid, Yugoslavia. We also thank Gary Roelofs for word processing the manuscript, and Leslie Fenn Christian and Robert Waldron for graphics.

\section{REFERENCES}

Alexander, J., 1972. Jugoslavia - Before the Roman Conquest. Thames and Hudson, London, 175 pp.

Allen, H. L. and Ocevski, B. T., 1976. Limnological studies in a large, deep, oligotrophic lake (Lake Ohrid, Yugoslavia). Arch. Hydrobiol., 77(1): 1-21.

Bottema, S., 1967. A late Quaternary pollen diagram from Ioannina, northwestern Greece. In: E. S. Higgs, C. Vita-Finzi, D. R. Harris and H. E. Fagg (Editors), The Climate, Environment and Industries of Stone Age Greece: III. Proc. Prehist. Soc., 33 : $1-29$.

Broecker, W. S. and Walton, A., 1959. The geochemistry of ${ }^{14} \mathrm{C}$ in fresh-water systems. Geochim. Cosmochim. Acta, 16:15-38.

Brugam, R. B., 1979. A re-evaluation of the Araphidineae/Centrales index as an indicator of lake trophic status. Freshwater Biol., 9(5): 451-460.

Chernyaeva, G. P., 1970. Diatoms of the bottom sediments of north Baikal. In: G. A. Dmitriev (Editor), Benthic Deposition in Baikal. Nauka, Moscow, pp. 144-156.

Davis, M. B. and Brubaker, L. B., 1973. Differential sedimentation of pollen grains in lakes. Limnol. Oceanogr., 18: 635-646.

Dean, W. E., 1974. Determination of carbonate and organic matter in calcareous sediments and sedimentary rocks by loss on ignition: comparison and other methods. J. Sediment. Petrol., 44(1): 242-248.

Deevey, E. S., Gross, M. S., Hutchinson, G. E. and Kraybill, H. L., 1954. The natural ${ }^{14} \mathrm{C}$ content of materials from hard-water lakes. Proc. Natl. Acad. Sci. U.S.A., 40: 285-288.

Hustedt, F., 1945. Diatomeen aus Seen und Quellgebieten der Balkan-Halbinseln. Arch. Hydrobiol., 40(4): 867-973. 
Ivanovski, T. and Strackov, M., 1974. Tectonics and history of the tectonic evolution of Ohrid Valley and its outskirts. In: Symposium on the Problems of the Regulation of Lake Ohrid (in Macedonia). Maced. Acad. Sci., Skopje, pp. 17-29.

Jurilj, A., 1954. Flora and vegetation of diatoms from Ochrida Lake in Yugoslavia (in Serbo-Croatian). Yugosl. Acad. Sci., Zagreb, 26: 99-190.

Kozarov, G., 1954. Contributions à la connaissance de Cyclotella fottii, Hustedt, diatomée planctonique du lac d'Ohrid. Recl. Trav. Stat. Hydrobiol. Ohrid, Ann. II, 3(9): 39-51.

Kozarov, G., 1958. La teneur en $\mathrm{SiO}_{2}$ et le développement de la population des diatomées dans le lac d'Ohrid au cours de 1957. Recl. Trav. Stat. Hydrobiol. Ohrid, Ann. VI, $1(17): 1-8$.

Kozarov, G., 1959. Organic production of phytoplankton in Lake Ohrid during the course of 1958. Recl. Trav. Stat. Hydrobiol. Ohrid, Ann. VII, 11(44): 1-10.

Kozarov, G., 1960. The phytoplankton investigations in Lake Prespa during the course of three years. Recl. Trav. Stat. Hydrobiol. Ohrid, Ann. VIII, 4(49): 1-52.

Lehman, J. T., 1975. Reconstructing the rate of accumulation of lake sediment: The effect of sediment focusing. Quaternary Res., $5: 541-550$.

Mori, S. and Horie, S., 1975. Diatoms in a $\mathbf{1 9 7 . 2}$ meters core sample from Lake Biwa-ko. Proc. Jpn Acad., 51: 675-679.

Munsell Soil Color Charts, 1975 Edition. Kollmorgen Corp., Bal timore, Md., unpag.

Ocevski, B., 1953. Rapports quantitatifs des bacteries dans le plancton du lac d'Ohrid. Recl. Trav. Stat. Hydrobiol. Ohrid, 6: 123-131.

Ocevski, B., 1958a. The bacterial flora of Ohrid Lake. Recl. Trav. Stat. Hydrobiol. Ohrid, Ann. VI, 9(25): 12-16.

Ocevski, B., 1958b. Changes of the population of heterotrophic bacteria in a 10 days' period (from 5.VII to 16 .VII 1955 year) in the season of maximum density of the planktons' population in Ohrid Lake. Recl. Trav. Stat. Hydrobiol. Ohrid, Ann. VI, 10(26): $1-11$.

Robbins, J. A., 1978. Geochemical and geophysical applications of radioactive lead. In: J. O. Nriagu (Editor), Biogeochemistry of Lead in the Environment. Elsevier, Amsterdam, pp. 285-393.

Schelske, C. L., Feldt, L. E., Santiago, M. A. and Stoermer, E. F., 1972. Nutrient enrichment and its effect on phytoplankton production and species composition in Lake Superior. Proc. 15th Conf. Great Lakes Res., pp. 149-165.

Schmidt, A., 1874-1927. Atlas der Diatomaceenkunde. O. R. Reisland, Leipzig, Pl. 1460.

Serafimova-Hadžiščce, P. J., 1959. La contribution a la connaissance de la repartition horizontale du zooplankton dans le lac d'Ohrid. Recl. Trav. Stat. Hydrobiol. Ohrid, Ann. VII, 3(36): 1-23.

Shannon, C. E. and Weaver, W., 1949. The mathematical theory of communication. Univ. Illinois Press, Urbana, Ill., 117 pp.

Stanković, S., 1960. The Balkan Lake Ohrid and Its Living World. Junk, Den Haag, 357 pp.

Stanković, S. and Hadžiš̌e, S., 1953. La thermique du lac d'Ohrid. Recl. Trav. Stat. Hydrobiol. Ohrid, 1: 1-61.

Stanković, S. and Sapkarev, J., 1959. La zone à coquilles du lac de Prespa (Macedoine). Recl. Trav. Stat. Hydrobiol. Ohrid, Ann. VII, 8(41): 1-13.

Stevenson, A. L., 1968. A new technique for obtaining uniform volume and sediment samples for pollen analysis. Pollen Spores, 10(2): 463-464.

Stockner, J. G., 1971. Preliminary characterization of lakes in the Experimental Lakes Area, northwestern Ontario using diatom occurrence in sediments. J. Fish. Res. Board Can., 28: 265-275.

Stockner, J. G. and Benson, W. W., 1967. The succession of diatom assemblages in the Recent sediments of Lake Washington. Limnol. Oceanogr., 12: 513-532.

Van der Hammen, T., Wijmstra, T. A. and Zagwijn, W. H., 1971. The floral record of the Late Cenozoic of Europe. In: K. K. Turekian (Editor), The Late Cenozoic Glacial Ages. Yale Univ. Press, New Haven, CT, pp. 391-424. 
West, R. G., 1968. Pleistocene Geology and Biology. Longmans, Green and Co., London, $377 \mathrm{pp}$.

Wetzel, R. G., 1975. Limnology. Saunders, Philadelphia, Pa., 743 pp.

Wetzel, R. G. and Manny, B. A., 1978. Postglacial rates of sedimentation, nutrient and fossil pigment deposition in a hardwater marl lake of Michigan. Pol. Arch. Hydrobiol., 25(1/2): 453-469.

Wijmstra, T. A., 1969. Palynology of the first 30 metres of a $120 \mathrm{~m}$ deep section in northern Greece. Acta Bot. Neerl., 18(4): 511-527. 